\title{
A Discussion on the Scene Feeling of Ink Scenery Painting
}

\author{
Chen Yu \\ School of Art and Design, Wuhan University of Technology, Wuhan, Hubei 430070
}

893775916@qq.com

Keywords: ink painting; scenery; painting; scene feeling

\begin{abstract}
The differences between ink scenery painting and traditional ink landscape painting lie in the scene feeling and timeliness, which are the innovative pulses to be solved urgently. Thus, nutrients should be obtained from the traditional techniques. The imitation and the appreciation are necessary. In addition, thinking is indispensable. The artistic conception of the scenery on the paper can be rejuvenated only by the artist's good traditional techniques and the immediate creation.
\end{abstract}

\section{Introduction}

Ink scenery painting plays an increasingly important identity property along with the fever of painting from nature, and the topic of involving ink painting into the scenery painting gradually shows its creative value and significance. As for these two words ink painting, it is not difficult to find that the former means more Chinese elements, while the latter is accompanied by strong Western elements. Now they are combined together, leaving people to reconsider the definition of the identity of ink scenery painting and its value appeal. Obviously, it should be mentioned that the concept of scenery in the paper is not exactly the "landscape" in the Western art, but the scenery concept under the context of Chinese and Western cultures.

\section{Why is Ink Scenery Painting Discussed in this Paper?}

When talking about the ink scenery painting, it is obviously that the scenery painting under the category of ink painting will be associated with. Then, the reason of the use of "ink scenery painting" instead of "ink landscape painting" is inseparable from the current painting fever. Absolutely, according to the concept of traditional Chinese painting, the weird phenomenon that many people swarm to the famous mountains should not exit in today's scenery painting. Since ancient times, Chinese painters admire the criterion of "art comes from life, but also needs an artist's inspiration and creation to make it a piece of art”. [1] Even Huang Binhong, a contemporary landscape painter, has not fallen into the stage of painting for painting. However, nowadays, many artists, especially Chinese painters who are engaged in the creation of ink painting, only focus on the depicting and portraying of scenes and are far away from being able to control the painting scene. If, in the strict sense, an ink scenery painting does not have the concept of scenery, even if the artist walks into the scene, he cannot express his sense of the scene. On the contrary, these artists can only copy the the scenery paintings of the past and even imitate the paintings in the Jiziyuan Paintings, shamelessly copying the texturing methods, ink techniques and even the viewing methods of ancient painters. Thus, their painting works lack of the scene feeling completely. For this kind of "ink landscape painting" works, I would rather call it "landscape painting”. Nowadays, the painting fever has, to some extent, implied that breaking through traditional stereotypes is an extremely urgent task for every artist.

The juxtaposition of "scenery" and ink painting in the paper is aimed at rethinking the value and significance of current and future painting, and at the same time, at recognizing the effectiveness of the contemporary transformation of scenery painting. As the saying goes, "the essence of art is innovation”. The history of art focuses more on its turning point, not on continuity, and certainly, the writing of art history will not repeat the old things. Instead, it will strive to expect the emergence of a new artistic language. The reconsideration of the concept of "ink scenery" is conducive to the 
evolution and development of scenery painting in the future. The concept of scene is more in line with the current social scenery form, while the concept of scenery leaves people the impression of being otherworldly. The involvement of scenery into ink painting can generate not only a breakthrough in the form of language, but also the contemporary value of ink painting. It can be said that the scenery is the product of reality, while the landscape is the product of ideality. Actually, if the concept of scenery is still adopted in the contemporary society, it is difficult to be in line with the ever-changing picture of urban life. Likewise, scenery painting is no longer a defining area of the outskirts of the city but the entire urban life landscape.

\section{The "Skill” and “Tao" of Ink Scenery Painting}

In China, there have been many wisdom discourses and allusions about "skill” and "Tao" since ancient times. The scenery painting is aimed at the entire nature, not the small-scale nature except the city. Thus, how to depict various different landscapes at the moment is rather important. Shi Tao of the Qing Dynasty once said: “The brush and ink should follow the times.”[2] Likewise, Fu Baoshi once stated: "The brush and ink should be changed along with the changing of times". These sayings are to indicate that the development of brush and ink must be related to the development of the era. At the same time, a matter of degree exists between the two. If one is too progressive, he will not be recognized by the people of the time; while if he is too reserved, he will be criticized. Thus, the question of the artistic conception of the works should be discussed. The ultimate purpose of "skill" and "Tao" is to construct the artistic concept behind the works, thus establishing the artistic height of the works. Thus, the skills turn to be important in painting, and that is what the so-called "the skill goes beyond Tao" means [3]. Painting is not just "painting" and it should focus on its transformative creation. In the history of Chinese art, there are numerous painters who have created the texturing methods, brush techniques and ink skills, which are closely related to painting. The painting is not just imitation, which is of no great benefits, of trees and stones. We have to seek for its laws and the using methods of brush and ink. That's to say, we need to ask why it is so. Carefully imitating, we can make others' advantages become our strengths, and thus the efforts will take effect. [4] If one has an opportunity to visit the Jiangnan, Taihang and Loess Plateau areas and see the real landscapes, he can compare the ancient painting methods and guess what the painters have done through repeated practice to create this style and texturing method. Hence, the imitation will no longer just follow the beaten track. Besides, when one comes across different landscapes and learns from other painters' experiences, he can also create new styles and texturing methods, and if he complies with the objects, he can use them for his own sake.

Ink scenery painting is an essential cultivation course for many artists today. The art styles and techniques in the art history have experienced the test of time, and are inherited and developed by the successors.

\section{Contemporary Significance of Ink Scenery Painting}

With the planarization of information in the current artistic creation environment, painting turns to be one of the best choices for artistic creators. This is also the fact that has been repeatedly proved by the history of art from ancient to modern times. Evidently, ink scenery painting is not limited to the mode of painting for the sake of painting. The creation should not only absorb nutrients from tradition but also need to pay attention to the current environment. Actually, tradition is not static but dynamic as it is constantly developing. The innovation at present will also turn into the tradition of the past with time passing. Scenery painting covers a wide range of objects, such as character scenes, natural environments, and urban landscapes. The contemporary significance of ink scenery painting can be reshaped through ink painting. Painting is the way to learn but not the end point. Nowadays, the concept of scenery painting has long surpassed the narrow understanding that painting is merely the creation of materials collection. Indeed, painting can be a new way of creation. Without painting, there would be no development and writing of art history.

In addition to recognizing the importance of painting for artistic creation, the painters should also 
make their subjective initiative take effects. The so-called subjective initiative must be based on the painting object, otherwise it is to eliminate the painting itself. Since the role of painting is recognized, then the value and boundaries of painting should be developed. Why is the ink scenery painting discussed here? Firstly, it is based on the development dilemma of contemporary ink painting. However, many contemporary ink paintings are increasingly losing its traditional elements, and furthermore, they can not be classified completely as ink paintings. However, this is not always the case. Many artists have always felt that the intervention of ink is an expression of closeness to tradition, so that the ink paintings break away from the tradition and become fashionable. It seems that if the ink is not intervened, the ink paintings will not be contemporary. As a result, on the one hand, many contemporary ink paintings are completely out of the category of ink painting, but at the same time, they are expected to be admitted to contemporary art field. On the other hand, the traditional ink painting can be transformed through painting, taking a pioneering and innovative approach of development. Secondly, the concept of landscape cannot guarantee the future of ink painting. With the advent of economic globalization, especially the acceleration of urbanization, the search for a purely natural landscape has become a fancy, and the countryside is no longer a poetic place. The poetic landscape atmosphere is being ruthlessly destroyed because of the heavy haze. It is the fact that the scenery has been replaced by the landscape. Thirdly, the painting fever is restless. The artists who are eager for quick success will be even more disturbing when engaging in painting. Nowadays, only a few artists truly understand the true essence of painting, but the reality is that they are blindly optimistic and pretending to be entertaining. Painting can not solve the creation

problem of all artists. When an artist is not qualified for the skills of brush and ink, he can do nothing to grasp the painting. Therefore, for scenery painting, especially ink scenery painting, the painters need to pay attention to the stage and reserve of painting.

\section{Conclusion}

The artist's ink scenery painting is different from that of other types of landscape paintings. It is characterized by its timeliness. Unlike oil painting, ink painting can be changed repeatedly. In view of the way of painting and the characteristics of ink painting, emphasis should be put on the scene feeling. The volatile characteristics of ink, and the relationship between water and ink, determine that the creator must adapt spontaneously and act decisively. Moreover, the scenery itself also has a kind of vitality, or a sense of tension of existence, which is the atmosphere of the scene built between people and objects. For a piece of art work, the viewers are expecting instinctively for vitality and tension, and perhaps this is the artistic concept of the work.

\section{References}

[1] Yanyuan, Zhang. Notes of Famous Paintings of the Past Dynasties. Zhejiang People's Fine Arts Publishing House, 2011:68.

[2] Yuanbin, Zhou. The Record of Kugua Monk Drawing Language. Shandong Pictorial Publishing House, 2007:31.

[3] Yong, Fang. Chuang Tzu (introduction and arrangement). Zhonghua Book Company, 2016:87.

[4] Heng, Lu. A Brief Discussion on Lu Yanshao's Landscape Painting. Shanghai People's Fine Arts Publishing House, 2016:22. 